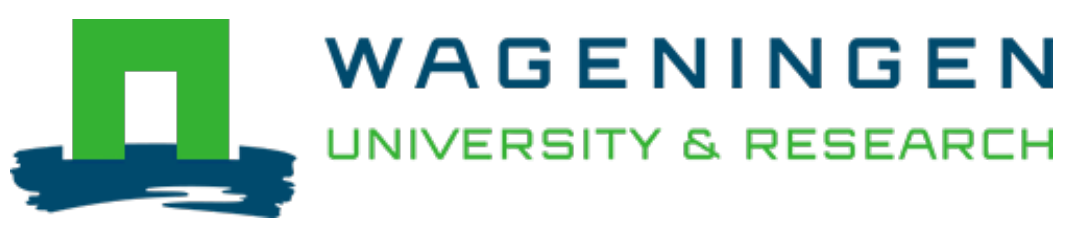

\title{
Effects of temperature and relative humidity on growth and enzyme production by Actinomucor elegans and Rhizopus oligosporus during sufu pehtze preparation
}

\author{
Food Chemistry \\ Han, B.; Ma, Y.; Rombouts, F.M.; Nout, M.J.R. \\ https://doi.org/10.1016/S0308-8146(02)00347-3
}

This publication is made publicly available in the institutional repository of Wageningen University and Research, under the terms of article $25 \mathrm{fa}$ of the Dutch Copyright Act, also known as the Amendment Taverne. This has been done with explicit consent by the author.

Article 25 fa states that the author of a short scientific work funded either wholly or partially by Dutch public funds is entitled to make that work publicly available for no consideration following a reasonable period of time after the work was first published, provided that clear reference is made to the source of the first publication of the work.

This publication is distributed under The Association of Universities in the Netherlands (VSNU) 'Article $25 \mathrm{fa}$ implementation' project. In this project research outputs of researchers employed by Dutch Universities that comply with the legal requirements of Article $25 \mathrm{fa}$ of the Dutch Copyright Act are distributed online and free of cost or other barriers in institutional repositories. Research outputs are distributed six months after their first online publication in the original published version and with proper attribution to the source of the original publication.

You are permitted to download and use the publication for personal purposes. All rights remain with the author(s) and / or copyright owner(s) of this work. Any use of the publication or parts of it other than authorised under article $25 \mathrm{fa}$ of the Dutch Copyright act is prohibited. Wageningen University \& Research and the author(s) of this publication shall not be held responsible or liable for any damages resulting from your (re)use of this publication.

For questions regarding the public availability of this publication please contact openscience.library@wur.nl 


\title{
Food Chemistry
}

\section{Effects of temperature and relative humidity on growth and enzyme production by Actinomucor elegans and Rhizopus oligosporus during sufu pehtze preparation}

\author{
Bei-Zhong Han ${ }^{\mathrm{a}, \mathrm{b}}$, Yong Ma ${ }^{\mathrm{b}}$, Frans M. Rombouts ${ }^{\mathrm{a}}$, M.J. Robert Nout ${ }^{\mathrm{a}, *}$ \\ ${ }^{a}$ Laboratory of Food Microbiology, Wageningen University, PO Box 8129, 6700 EV Wageningen, The Netherlands \\ ${ }^{\mathrm{b}}$ College of Food Science and Engineering, China Agricultural University, Beijing 100083, China
}

Received 22 March 2002; received in revised form 11 July 2002; accepted 19 July 2002

\begin{abstract}
Sufu is a Chinese soybean cheese obtained after maturation of solid-state mould-fermented tofu. Ambient temperatures of 30 $35^{\circ} \mathrm{C}$ during the summer season prohibit the use of the usual starter Actinomucor elegans. We compared the properties of the latter with a potential alternative starter Rhizopus oligosporus that could be used at higher temperatures. The effects of temperature and relative humidity on growth rate of Actinomucor elegans and Rhizopus oligosporus were optimum at $25^{\circ} \mathrm{C}$ at $\mathrm{RH} 95-97 \%$, and $35{ }^{\circ} \mathrm{C}$ at RH 95-97\%, respectively. Yields of protease (108 U/g pehtze), lipase (172 U/g) and glutaminase (176 U/g) by A. elegans were maximum after $48 \mathrm{~h}$ at $25^{\circ} \mathrm{C}$ and $\mathrm{RH} 95-97 \%$, and for $\alpha$-amylase $(279 \mathrm{U} / \mathrm{g}$ pehtze $)$ and $\alpha$-galactosidase $(227 \mathrm{U} / \mathrm{g})$ at $30{ }^{\circ} \mathrm{C}$ and $\mathrm{RH}$ $95-97 \%$ after 48 and $60 \mathrm{~h}$ of incubation. Highest protease (104 U/g pehtze), and lipase (187 U/g) activities of R. oligosporus were observed after $48 \mathrm{~h}$ at $35^{\circ} \mathrm{C}$ and $\mathrm{RH} 95-97 \%$, while maximum $\alpha$-amylase (288 $\mathrm{U} / \mathrm{g}$ pehtze) and glutaminase (187 U/g) activities were obtained after $36 \mathrm{~h}$ at $35^{\circ} \mathrm{C}$ and RH 95-97\%. Maximum $\alpha$-galactosidase activity (226 U/g) by R. oligosporus was found after $36 \mathrm{~h}$ at $30{ }^{\circ} \mathrm{C}$ and $\mathrm{RH} 95-97 \%$. It is concluded that $R$. oligosporus is a potential alternative to A. elegans as sufu pehtze starter during hot seasons.
\end{abstract}

(C) 2002 Elsevier Science Ltd. All rights reserved.

Keywords: Sufu pehtze; Actinomucor elegans; Rhizopus oligosporus; Enzyme activity

\section{Introduction}

Sufu, $F u-r u$ written in hieroglyphics, is a traditional Chinese fermented soybean curd and a highly flavoured, soft creamy cheese-type product, which can be used in the same way as cheese (Steinkraus, 1996; Su, 1986). This fermented product has been widely consumed by Chinese people as an appetizer for many centuries.

There are many different types of sufu, produced by different local processes in China (Wang \& Du, 1998); mould-fermented sufu is the most popular type (Han, Rombouts, \& Nout, 2001). Four stages are involved in preparing this type of sufu: (1) Preparing tofu (soybean curd), (2) Preparing pehtze (pizi) by fungal solid-state

* Corresponding author. Tel.: +31-317-482834; fax: +31-317484978.

E-mail address: rob.nout@micro.fdsci.wau.nl (M.J.R. Nout). fermentation of tofu, (3) Salting of pehtze, (4) Ripening in dressing brine (Wang \& Hesseltine, 1970).

Pehtze, fresh soybean curd overgrown with fungal mycelium is produced by means of solid-substrate fermentation after inoculation (about $48 \mathrm{~h}$ ) with pure culture moulds. In commercial practice, Actinomucor spp., Mucor spp and Rhizopus spp. are used for sufu preparation. Among them, Actinomucor elegans and Actinomucor taiwanensis seem to be the most frequently used for commercial sufu production in China. However, these two mould species only grow well at $25-30{ }^{\circ} \mathrm{C}$, so it is impossible to produce sufu during the hot summer with indoor factory temperatures reaching $35{ }^{\circ} \mathrm{C}$ or even higher (Han et al., 2001). Since Rhizopus oligosporus grows well at higher temperatures (up to $40{ }^{\circ} \mathrm{C}$; Han \& Nout, 2000), it might be used as a starter to produce sufu during this season.

Protein is the main component in tofu. Among the fungal enzymes formed on tofu, proteases have received 
much attention. Using wheat bran, wheat, and soybean as substrates, Wang, Vespa, and Hesseltine (1974) investigated the incubation conditions for maximum production of acid protease by Mucor dispersus, A. elegans and $R$. oligosporus. Whereas Chou, Ho, and Tsai (1988) studied the enzymes produced by $A$. taiwanensis on tofu, there are few published data describing the enzymes produced by $A$. elegans and $R$. oligosporus during sufu pehtze preparation.

In the present study, we determined the effects of physical process parameters that can be monitored and controlled easily under factory conditions. As criteria for the comparison of the two fungal species, we selected relative humidity, incubation temperature and time, and studied their relation with the growth of A. elegans and $R$. oligosporus by measuring their biomass increment, and their enzyme production during the preparation of pehtze. Protease, lipase, $\alpha$-amylase, glutaminase, and $\alpha$ galactosidase, affecting the flavour and texture of sufu during the ripening period, were assessed.

\section{Materials and methods}

\subsection{Microorganisms}

Actinomucor elegans [Academia Sinica (AS) 3.227] and Rhizopus oligosporus (NRRL 5905) isolated originally from commercial sufu and tempe, respectively, were grown on malt extract agar (MEA, Oxoid CM 59) and maintained at $4{ }^{\circ} \mathrm{C}$. After incubation at $30{ }^{\circ} \mathrm{C}$ for 5 days, spore suspensions $\left(\sim 10^{5} \mathrm{cfu} / \mathrm{ml}\right)$ were harvested by scraping the sporangia off the agar and suspending them into sterile distilled water with $0.85 \%$ salt, $0.1 \%$ peptone and $0.05 \%$ Tween 80 . For each series a fresh spore suspension was prepared.

\subsection{Determination of biomass formation rate $\left[d\left(\mathrm{x}^{1 / 3}\right)\right]$ $d \mathrm{t}]$ on membrane-covered tofu}

The tofu used for biomass monitoring was provided by Beijing WangZhiHe sufu manufacture, and was cut into circular pieces (diam $8.5 \mathrm{~cm} \times$ height $0.8 \mathrm{~cm}$ ) and then immersed in $1 \% \mathrm{w} / \mathrm{v}$ citric acid solution for $5 \mathrm{~min}$ to inhibit growth of contaminating microbes. Proximate analysis of the tofu revealed that it contained approximately $76.8 \%$ moisture, $12.5 \%$ crude protein, $5.7 \%$ crude lipid, and 3.2\% carbohydrate. The piece of tofu was fitted into a sterile glass Petri dish, and a membrane (Nylon Transfer Membrane, Schleicher \& Schuell, no: 10416116, Pore hole $0.45 \mu \mathrm{m}$ ) was placed onto the tofu (Nagel, Oostra, Tramper, \& Rinzema, 1999). The membrane-covered tofu was inoculated at the centre of the membrane with a drop $(0.02 \mathrm{ml})$ of spore suspension, and then incubated in a ventilated climate incubator at controlled temperature $\left(20,25,30,35\right.$ or $\left.40{ }^{\circ} \mathrm{C}\right)$ and controlled relative humidity $(\mathrm{RH})(73-75,84-86$, or $95-$ $97 \%$ ).

At regular intervals duplicate Petri dishes were removed, and mycelium with membrane was taken off from a tofu. Subsequently the mycelium was dried for 2 days at $80{ }^{\circ} \mathrm{C}$, and the mycelial dry weight was determined gravimetrically.

Growth curves based on the cubic root of mycelial dry weights were fitted using linear regression (Microsoft Excel) to determine the biomass formation rate $\left[\mathrm{d}\left(x^{1 / 3}\right) / \mathrm{d} t\right]$ (Han \& Nout, 2000).

\subsection{Pehtze preparation}

Tofu, as mentioned earlier, was cut into pieces $(3.2 \times 3.2 \times 1.6 \mathrm{~cm})$ for pehtze preparation. The pieces were inoculated with $A$. elegans and $R$. oligosporus, respectively, by spraying spore suspension onto the surface of each. The inoculated tofu was placed evenly spaced in plastic trays, and incubated in a ventilated climate incubator, at controlled temperature $(25,30$, or $35^{\circ} \mathrm{C}$ ) and controlled RH (73-75, 84-86, or 95-97\%). Fresh pehtze (or tofu if not real pehtze) were obtained for analyses after being incubated for 12, 24, 36, 48, and $60 \mathrm{~h}$.

\subsection{Enzyme assays}

\subsubsection{Crude extracts}

Duplicate pehtze samples (about $10 \mathrm{~g}$ ) were mixed with $50 \mathrm{ml}$ of $0.3 \mathrm{M} \mathrm{NaCl}$ and $0.2 \mathrm{M}$ phosphate buffer (pH 6.8) and homogenized in a blender. They were kept at room temperature for $60 \mathrm{~min}$ with frequent stirring, and then centrifuged at $2100 \times g$ for $5 \mathrm{~min}$. The supernatant was used as crude enzyme extract. All samples were analysed in duplicate $(n=4)$.

\subsubsection{Protease activity}

The method mentioned by Kruger (1973) was used. 2 $\mathrm{ml}$ of crude enzyme extract and $2 \mathrm{ml}$ of $2.4 \%$ azocasein (Sigma A-2765) dissolved in $0.05 \mathrm{M}$ McIlvaine citric acid-disodium phosphate buffer ( $\mathrm{pH}$ 6.0) were mixed. The mixture was then shaken gently for $2 \mathrm{~h}$ in a shaking bath at $35{ }^{\circ} \mathrm{C}$. The reaction was terminated by addition of $5 \mathrm{ml}$ of $10 \% \mathrm{TCA}$, and the mixture was filtered. $5 \mathrm{ml}$ of $0.5 \mathrm{M} \mathrm{NaOH}$ was added to $5 \mathrm{ml}$ of the filtrate and after 20 min the absorbance of the solution was read at $440 \mathrm{~nm}$. One unit of protease activity is defined as an absorbance $(440 \mathrm{~nm})$ change of 0.01 after $2 \mathrm{~h}$ at $35^{\circ} \mathrm{C}$. (UV-vis Spectrophotometer, UV mini 1240, SHIMADZU, Japan)

\subsubsection{Lipase activity}

Titrimetric determination of lipase (Lipase kit, Sigma Catalogue no. 800-B) was carried out. A mixture of 1.0 $\mathrm{ml}$ crude enzyme extract, $2.5 \mathrm{ml}$ water, $3.0 \mathrm{ml}$ Sigma 
Lipase Substrate (Catalogue no. 800-1), and $1.0 \mathrm{ml}$ TRIZMA Buffer (Sigma Catalogue no. 800-2) was shaken at $37^{\circ} \mathrm{C}$ for $6 \mathrm{~h}$. The reaction was stopped by adding 3.0 $\mathrm{ml} \mathrm{95 \%}$ ethanol, and 4 drops of Thymolphthalein Indicator Solution (Catalog No. 800-3) were added, followed by titration with $0.05 \mathrm{M} \mathrm{NaOH}$ solution until a slight blue colour was observed. Sigma-Tietz Units of lipase are equal to the volume $(\mathrm{ml})$ of $0.05 \mathrm{M} \mathrm{NaOH}$ required to neutralize the fatty acids liberated during the incubation. Lipase activity in Sigma-Tietz Units $/ \mathrm{ml}$ was converted to International Units multiplying by 280 .

\subsection{4. $\alpha$-Amylase}

The activity of $\alpha$-amylase was determined by a colorimetric method as follows. The reaction mixture, which contained $10 \mathrm{ml}$ of $1 \%$ soluble starch and $5 \mathrm{ml}$ of $0.1 \mathrm{M}$ phosphate buffer ( $\mathrm{pH}$ 6.0), was equilibrated at $60{ }^{\circ} \mathrm{C}$ for $5 \mathrm{~min}$. Then, $1.0 \mathrm{ml}$ of the crude enzyme extract was added into the mixture and it was kept at $60{ }^{\circ} \mathrm{C}$ for 10 min. Next, $1 \mathrm{ml}$ of the mixture was added to $5 \mathrm{ml}$ of a solution containing $0.44 \mathrm{mg}$ iodine and $0.2 \mathrm{~g} \mathrm{KI}$. The absorbance of the solution was measured at $660 \mathrm{~nm}$, and $\alpha$-amylase activity was calculated using a standard curve made with commercial $\alpha$-amylase (Microbiologial Media Product, Beijing). For practical reasons we defined one unit of $\alpha$-amylase as the activity catalysing the hydrolysis of $1 \mathrm{ml}$ of $1 \%$ starch solution in $1 \mathrm{~h}$ under the assay conditions, in comparison with $\alpha$-amylase of known activity.

\subsubsection{Glutaminase}

A modification of the method of Moriguchi, Sakai, Tateyama, Furuta, and Wakayama (1994) was used, monitoring the formation of L-glutamate with L-glutamate dehydrogenase. The reaction mixture contained $100 \mathrm{mM}$ Tris- $\mathrm{HCl}$ buffer ( $\mathrm{pH} 7.5), 30 \mathrm{mM}$ L-glutamine (Sigma G-3126), 5\% NaCl and crude enzyme extract $(0.1 \mathrm{ml})$ in a final volume of $0.5 \mathrm{ml}$. After being allowed to react for $10 \mathrm{~min}$ at $30{ }^{\circ} \mathrm{C}$, the reaction was terminated by boiling for $3 \mathrm{mn}$. $50 \mathrm{mM}$ Tris-hydrazine buffer $(\mathrm{pH}$ 9.0), 1.5 mM NAD ${ }^{+}$(Sigma N-7004), $0.5 \mathrm{mM}$ ADP (Sigma A-2754) and 5 units/ml of glutamate dehydrogenase (Sigma G-2501) were added in a total volume of $1.0 \mathrm{ml}$ to this supernatant after centrifugation (Centrifuge CT4D, HITACHI, Japan). The absorbance at 340 $\mathrm{nm}$ was measured after incubating the mixture for $1 \mathrm{~h}$ at $30{ }^{\circ} \mathrm{C}$. One unit of glutaminase activity was defined as a change in the absorbance at $340 \mathrm{~nm}$ of 0.1 at $30^{\circ} \mathrm{C}$.

\subsection{6. $\alpha$-Galactosidase}

The combined method described by Chou et al. (1988) and van den Broek, Ton, Verdoes, van Laere, Voragen, and Beldman (1999) was used. The reaction mixture, which contained $0.1 \mathrm{ml}$ of $0.01 \mathrm{M}$ p-nitrophenyl- $\alpha$-Dgalactopyranose (PNPG, Sigma N-0877), $0.3 \mathrm{ml}$ of 0.2
M phosphate buffer ( $\mathrm{pH}$ 6.4), and $0.1 \mathrm{ml}$ of crude enzyme extract, was incubated at $37{ }^{\circ} \mathrm{C}$ for $20 \mathrm{~min}$. The reaction was stopped by adding an equal volume of 0.5 $\mathrm{M}$ glycine/ $\mathrm{NaOH}$ buffer ( $\mathrm{pH}$ 9) containing $2 \mathrm{mM}$ EDTA. The colour formation was measured at $400 \mathrm{~nm}$. The $\alpha$-galactosidase activity was then assayed by measuring the amount of $p$-nitrophenol liberated from PNPG at $37{ }^{\circ} \mathrm{C}$ in $20 \mathrm{~min}$ using a standard curve. One unit of $\alpha$-galactosidase was defined as the activity liberating $1 \mu \mathrm{g} p$-nitrophenol per min under the specified conditions.

\section{Results and discussion}

\subsection{Effect of incubation temperature and $\mathrm{RH}$ on fungal growth rate on membrane-covered tofu}

Previously, Chou et al. (1988) and Wang et al. (1974) monitored the growth by visual estimation, which only provides an indication of mycelial formation. In this study, a nylon membrane separated the mycelium from the tofu substrate. Previously, we found that fungal growth is not affected by the presence of a membrane, whereas this technique offers the possibility to separate the biomass and determine its weight. Similar experiments were reported by Mitchell, Doelle, and Greenfield (1989) and Nagel et al. (1999).

Fig. 1 shows the effect of incubation temperature and $\mathrm{RH}$ on the biomass formation rate expressed as $\left[\mathrm{d}\left(x^{1 / 3}\right) /\right.$ $\mathrm{d} t]$. RH levels varied from $73-75 \%$ to $95-97 \%$ and temperatures from $20{ }^{\circ} \mathrm{C}$ to $40{ }^{\circ} \mathrm{C}$. The optimum growth temperatures and RH for $A$. elegans and $R$. oligosporus were $25{ }^{\circ} \mathrm{C}$ at $95-97 \%$, and $35^{\circ} \mathrm{C}$ at $95-97 \%$, respectively. At constant temperature, the formation rates were positively correlated with $\mathrm{RH}$. The formation rate of $A$. elegans declined sharply at temperatures exceeding $30{ }^{\circ} \mathrm{C}$. On the other hand, the formation rate of $R$. oligosporus was still quite high at $40^{\circ} \mathrm{C}$.

\subsection{Effect of incubation temperature and RH on enzyme activities expressed in pehtze}

Protease production by $A$. elegans and $R$. oligosporus is presented in Table 1. The protease activities produced by the tested mould strains on tofu were considerably affected by the incubation temperature and humidity. At higher RH, higher protease activities were obtained. The highest protease activity (108 U/g of pehtze d.m.) of A. elegans was found after $48 \mathrm{~h}$ incubation at $25^{\circ} \mathrm{C}$ and RH 95-97\%. For $R$. oligosporus the highest activity (104 U/g of pehtze d.m.) was obtained after $48 \mathrm{~h}$ incubation at $35^{\circ} \mathrm{C}$ and $\mathrm{RH}$ 95-97\%.

$A$. elegans and $R$. oligosporus produced relatively high lipase activities on tofu under optimum conditions (Table 2). The highest lipase activity (172 U/g pehtze 

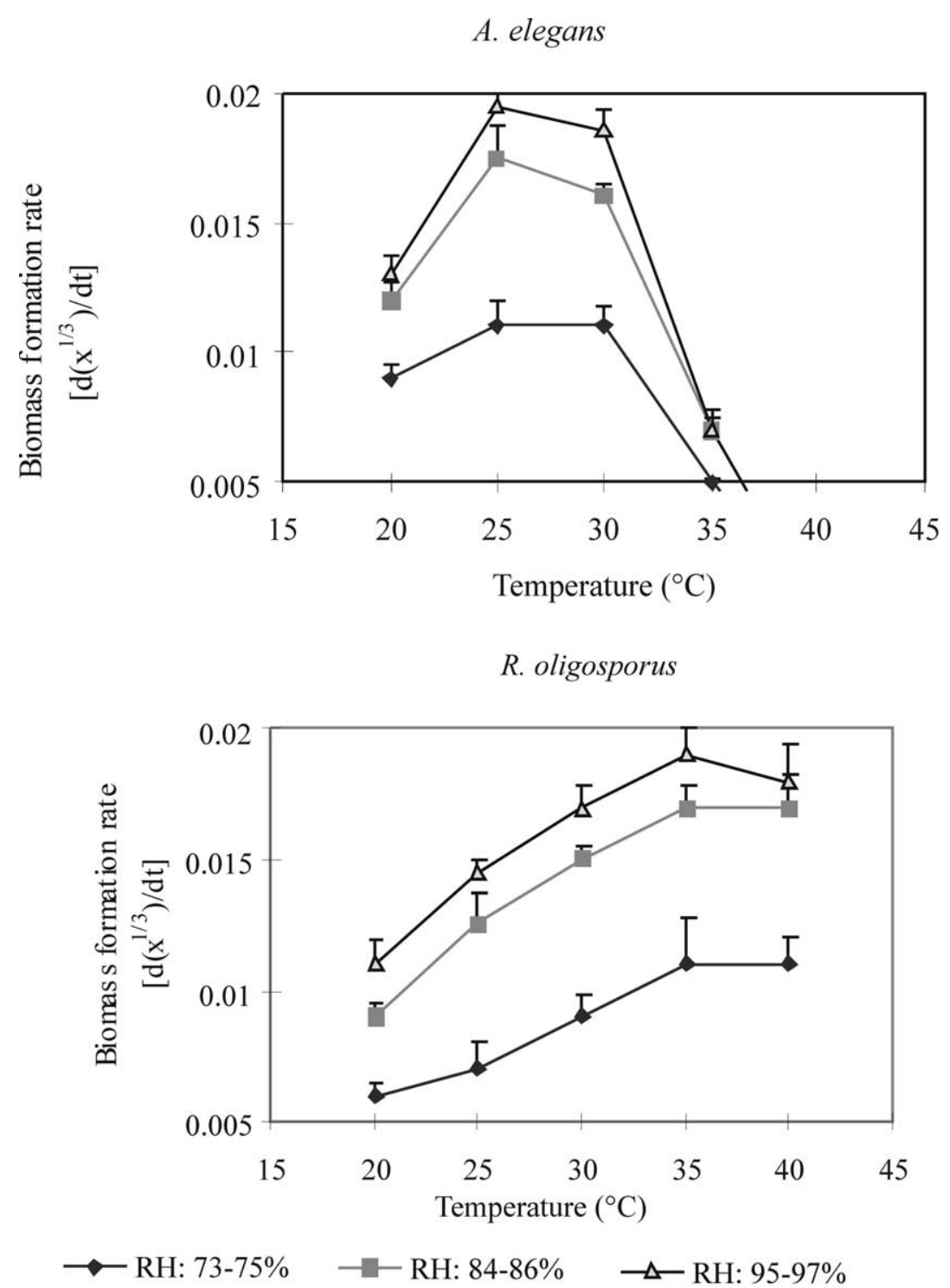

Fig. 1. Biomass formation rate $\left[\mathrm{d}\left(x^{1 / 3}\right) / \mathrm{d} t\right]$ of Actinomucor elegans AS3.227 and Rhizopus oligosporus NRRL5905 as a function of temperature and relative humidity.

d.m.) produced by $A$. elegans was found after $48 \mathrm{~h}$ incubation at $25{ }^{\circ} \mathrm{C}$ and $\mathrm{RH}$ 95-97\%. Although lipase activity produced by $R$. oligosporus was not strongly affected by incubation temperature and $\mathrm{RH}$, the maximum activity (187 U/g pehtze d.m.) was observed after $48 \mathrm{~h}$ incubation at $35^{\circ} \mathrm{C}$ and $\mathrm{RH} 95-97 \%$.

Similarly to the production of protease and lipase, $A$. elegans produced more $\alpha$-amylase activity at higher $\mathrm{RH}$ levels (Table 3). Although the optimum growth temperature for A. elegans was $25^{\circ} \mathrm{C}$, the highest yield of $\alpha$-amylase (279U/g pehtze d.m.) was observed after $48 \mathrm{~h}$ incubation at $30{ }^{\circ} \mathrm{C}$ and $\mathrm{RH}$ 95-97\%. The enzyme activity declined after $60 \mathrm{~h}$. R. oligosporus produced maximum $\alpha$-amylase activity (288 $\mathrm{U} / \mathrm{g}$ pehtze d.m.) after $36 \mathrm{~h}$ of incubation at $35^{\circ} \mathrm{C}$ and $\mathrm{RH} 95-97 \%$; the enzyme activity decreased after $48 \mathrm{~h}$.

Glutaminase is considered an important key enzyme for the palatable taste of fermented soybean foods $(\mathrm{Lu}$, $\mathrm{Yu}, \&$ Chou, 1996), and expectedly, the predominance of glutamate in sufu (Liu \& Chou, 1994) results from glutaminase activity. Glutamate in combination with salt $(\mathrm{NaCl})$ contributes to the flavour and hedonic characteristics of foods (Halpern, 2000). Table 4 shows that the highest glutaminase activity (176 U/g pehtze d.m.) of $A$. elegans was formed at $25^{\circ} \mathrm{C}$ and $\mathrm{RH} 95-97 \%$ after $48 \mathrm{~h}$ of incubation. The highest yield of glutaminase (187 $\mathrm{U} / \mathrm{g}$ pehtze d.m.) by $R$. oligosporus was observed at $35^{\circ} \mathrm{C}$ and $\mathrm{RH} 95-97 \%$ after $36 \mathrm{~h}$ of cultivation. Large amounts 
Table 1

Protease activity (U/g pehtze dry matter) production by Actinomucor elegans AS3.227 and Rhizopus oligosporus NRRL5905 at various incubation temperatures and relative humidities (RH)

\begin{tabular}{|c|c|c|c|c|c|c|c|c|c|c|c|c|c|c|c|c|}
\hline \multirow[t]{4}{*}{ Mould } & \multirow[t]{4}{*}{ RH (\%) } & \multicolumn{15}{|c|}{ Temperature $\left({ }^{\circ} \mathrm{C}\right)$} \\
\hline & & \multicolumn{5}{|l|}{25} & \multicolumn{5}{|l|}{30} & \multicolumn{5}{|l|}{35} \\
\hline & & \multicolumn{5}{|c|}{ Incubation time (h) } & \multicolumn{5}{|c|}{ Incubation time $(\mathrm{h})$} & \multicolumn{5}{|c|}{ Incubation time $(\mathrm{h})$} \\
\hline & & 12 & 24 & 36 & 48 & 60 & 12 & 24 & 36 & 48 & 60 & 12 & 24 & 36 & 48 & 60 \\
\hline \multirow[t]{3}{*}{ A. elegans } & $73-75$ & $4.4 \pm 0.8$ & $36.4 \pm 8.8$ & $58.3 \pm 10.0$ & $61.2 \pm 4.2$ & $60.3 \pm 5.6$ & $6.4 \pm 1.3$ & $43.4 \pm 7.4$ & $52.3 \pm 8.4$ & $61.2 \pm 5.4$ & $60.1 \pm 3.4$ & $2.3 \pm 0.1$ & $8.1 \pm 2.0$ & $13.3 \pm 3.0$ & $14.5 \pm 1.3$ & $14.3 \pm 1.1$ \\
\hline & $84-86$ & $5.2 \pm 0.7$ & $52.1 \pm 5.7$ & $64.0 \pm 5.1$ & $82.3 \pm 5.5$ & $75.2 \pm 4.7$ & $8.1 \pm 1.1$ & $53.1 \pm 3.0$ & $64.2 \pm 0.1$ & $81.9 \pm 11.2$ & $73.3 \pm 4.2$ & $2.2 \pm 0.3$ & $7.4 \pm 0.9$ & $11.4 \pm 1.6$ & $16.2 \pm 2.8$ & $12.3 \pm 0.5$ \\
\hline & $95-97$ & $5.2 \pm 0.8$ & $58.3 \pm 4.2$ & $80.4 \pm 5.9$ & $108 \pm 13.8$ & $90.3 \pm 8.6$ & $12.1 \pm 0.5$ & $56.3 \pm 1.2$ & $85.4 \pm 4.6$ & $96.3 \pm 5.9$ & $81.3 \pm 7.9$ & $2.1 \pm 0.2$ & $10.5 \pm 1.1$ & $12.3 \pm 1.1$ & $15.4 \pm 1.3$ & $16.4 \pm 1.6$ \\
\hline \multirow[t]{3}{*}{ R. oligosporus } & $73-75$ & $5.2 \pm 1.8$ & $38.4 \pm 4.0$ & $46.2 \pm 5.6$ & $61.9 \pm 1.9$ & $72.2 \pm 7.9$ & $6.3 \pm 1.6$ & $46.2 \pm 5.9$ & $69.5 \pm 4.5$ & $77.3 \pm 5.8$ & $58.7 \pm 6.7$ & $11.8 \pm 1.6$ & $57.9 \pm 4.9$ & $76.2 \pm 5.2$ & $86.8 \pm 6.2$ & $77.2 \pm 7.4$ \\
\hline & $84-86$ & $5.6 \pm 0.7$ & $46.1 \pm 5.7$ & $58.7 \pm 6.6$ & $78.4 \pm 3.1$ & $77.9 \pm 9.3$ & $6.2 \pm 0.9$ & $58.6 \pm 1.9$ & $78.3 \pm 1.2$ & $91.8 \pm 8.5$ & $87.7 \pm 7.5$ & $19.2 \pm 2.4$ & $67.5 \pm 1.2$ & $81.3 \pm 4.6$ & $97.1 \pm 3.5$ & $74.8 \pm 4.8$ \\
\hline & $95-97$ & $7.4 \pm 1.0$ & $39.3 \pm 4.2$ & $63.9 \pm 1.1$ & $72.3 \pm 8.3$ & $72.7 \pm 4.7$ & $7.2 \pm 1.3$ & $56.1 \pm 1.9$ & $82.5 \pm 6.2$ & $97.9 \pm 4.3$ & $91.4 \pm 5.6$ & $20.4 \pm 2.5$ & $64.5 \pm 1.5$ & $94.4 \pm 6.7$ & $104 \pm 8.8$ & $103 \pm 9.8$ \\
\hline \multicolumn{17}{|c|}{ Data represent averages \pm standard deviations of duplicate analyses of duplicate samples. } \\
\hline \multicolumn{17}{|c|}{ Table 2} \\
\hline Lipa & $(\mathrm{U} / \mathrm{g}$ peht & ze d.m.) pr & roduction by & у Actinoтисе & or elegans A & S3.227 and & Rhizopus o & ligosporus $\mathrm{\Lambda}$ & VRRI 5905 & at various in & ncubation to & emperatures & s and & 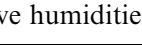 & $\mathrm{RH})$ & \\
\hline \multirow[t]{4}{*}{ Mould } & RH $(\%)$ & \multicolumn{15}{|c|}{ Temperature $\left({ }^{\circ} \mathrm{C}\right)$} \\
\hline & & \multicolumn{5}{|l|}{25} & \multicolumn{5}{|l|}{30} & \multicolumn{5}{|l|}{35} \\
\hline & & \multicolumn{5}{|c|}{ Incubation time $(\mathrm{h})$} & \multicolumn{5}{|c|}{ Incubation time $(\mathrm{h})$} & \multicolumn{5}{|c|}{ Incubation time $(\mathrm{h})$} \\
\hline & & 12 & 24 & 36 & 48 & 60 & 12 & 24 & 36 & 48 & 60 & 12 & 24 & 36 & 48 & 60 \\
\hline \multirow[t]{3}{*}{ A. elegans } & $73-75$ & $15.6 \pm 2.3$ & $56.2 \pm 7.4$ & 1138.1 & $123 \pm 9.9$ & $105 \pm 7.0$ & $14.2 \pm 1.7$ & $62.3 \pm 6.1$ & $96.4 \pm 7.3$ & $131 \pm 5.7$ & $105 \pm 6.1$ & $10.2 \pm 0.9$ & $35.2 \pm 2.6$ & $44.6 \pm 7.1$ & $56.4 \pm 3.1$ & $55.3 \pm 5.1$ \\
\hline & $84-86$ & $14.3 \pm 1.6$ & $88.3 \pm 5.5$ & $122 \pm 9.6$ & $146 \pm 5.7$ & $143 \pm 8.2$ & $16.7 \pm 2.3$ & $91.2 \pm 5.9$ & $118 \pm 7.4$ & $154 \pm 7.1$ & $137 \pm 4.2$ & $9.8 \pm 1.1$ & $37.3 \pm 3.5$ & $42.1 \pm 6.6$ & $62.8 \pm 3.8$ & $60.8 \pm 4.1$ \\
\hline & $95-97$ & $17.4 \pm 2.3$ & $93.6 \pm 6.7$ & $135 \pm 10.0$ & $172 \pm 11.3$ & $168 \pm 9.4$ & $17.3 \pm 1.1$ & $102 \pm 8.5$ & $120 \pm 5.8$ & $147 \pm 4.2$ & $135 \pm 10.0$ & $11.7 \pm 1.5$ & $31.2 \pm 2.8$ & $45.9 \pm 3.6$ & $59.2 \pm 4.1$ & $61.6 \pm 7.8$ \\
\hline \multirow[t]{3}{*}{ R. oligosporus } & $73-75$ & $12.3 \pm 1.2$ & $78.4 \pm 4.8$ & $90.6 \pm 7.7$ & $119 \pm 5.7$ & $123 \pm 9.3$ & 13.31 .6 & $84.3 \pm 6.1$ & $93.3 \pm 7.7$ & $128 \pm 8.4$ & $119 \pm 6.1$ & $12.5 \pm 1.0$ & $87.2 \pm 4.0$ & $99.1 \pm 9.7$ & $129 \pm 7.8$ & $115 \pm 5.1$ \\
\hline & $84-86$ & $16.8 \pm 1.4$ & $83.9 \pm 1.8$ & $127 \pm 3.8$ & $154 \pm 5.7$ & $158 \pm 6.9$ & $18.4 \pm 1.2$ & $96.8 \pm 4.0$ & $125 \pm 7.5$ & $169 \pm 11.3$ & $172 \pm 8.4$ & $19.7 \pm 2.3$ & $96.4 \pm 5.1$ & $143 \pm 12.4$ & $156 \pm 8.5$ & $155 \pm 9.7$ \\
\hline & $95-97$ & $15.8 \pm 1.7$ & $92.2 \pm 5.1$ & $133 \pm 10.2$ & $179 \pm 9.9$ & $170 \pm 6.4$ & $18.9 \pm 1.6$ & $106 \pm 5.7$ & $144 \pm 7.2$ & $177 \pm 10.1$ & $183 \pm 8.1$ & $20.1 \pm 2.6$ & $95.1 \pm 5.0$ & $148 \pm 11.6$ & $187 \pm 5.7$ & $178 \pm 9.9$ \\
\hline
\end{tabular}

Data represent averages \pm standard deviations of duplicate analyses of duplicate samples. 
Table 3

$\alpha$-Amylase activity (U/g pehtze d.m.) production by Actinomucor elegans AS3.227 and Rhizopus oligosporus NRRL5905 at various incubation temperatures and relative humidities (RH)

\begin{tabular}{|c|c|c|c|c|c|c|c|c|c|c|c|c|c|c|c|c|}
\hline \multirow[t]{4}{*}{ Mould } & \multirow[t]{4}{*}{ RH (\%) } & \multicolumn{15}{|c|}{ Temperature $\left({ }^{\circ} \mathrm{C}\right)$} \\
\hline & & \multicolumn{5}{|l|}{25} & \multicolumn{5}{|l|}{30} & \multicolumn{5}{|l|}{35} \\
\hline & & \multicolumn{5}{|c|}{ Incubation time (h) } & \multicolumn{5}{|c|}{ Incubation time $(\mathrm{h})$} & \multicolumn{5}{|c|}{ Incubation time (h) } \\
\hline & & 12 & 24 & 36 & 48 & 60 & 12 & 24 & 36 & 48 & 60 & 12 & 24 & 36 & 48 & 60 \\
\hline \multirow[t]{3}{*}{ A. elegans } & $73-75$ & $56.4 \pm 3.8$ & $157 \pm 4.2$ & $198 \pm 9.9$ & $231 \pm 4.2$ & $167 \pm 17.0$ & $67.4 \pm 3.5$ & $162 \pm 5.7$ & $206 \pm 5.7$ & $248 \pm 18.4$ & $187 \pm 9.9$ & $12.5 \pm 3.9$ & $34.3 \pm 4.2$ & $58.1 \pm 4.4$ & $79.2 \pm 11.8$ & $75.8 \pm 4.2$ \\
\hline & $84-86$ & $64.5 \pm 4.0$ & $167 \pm 5.7$ & $219 \pm 4.2$ & $251 \pm 4.2$ & $213 \pm 9.9$ & $76.2 \pm 9.9$ & $173 \pm 7.1$ & $227 \pm 4.2$ & $267 \pm 4.4$ & $235 \pm 14.1$ & $13.4 \pm 3.7$ & $38.6 \pm 1.1$ & $64.2 \pm 5.7$ & $86.7 \pm 6.4$ & $76.1 \pm 6.1$ \\
\hline & $95-97$ & $76.2 \pm 8.8$ & $178 \pm 5.7$ & $236 \pm 14.1$ & $269 \pm 5.7$ & $223 \pm 11.3$ & $88.4 \pm 4.5$ & $187 \pm 8.5$ & $243 \pm 4.2$ & $279 \pm 12.7$ & $226 \pm 5.7$ & $11.4 \pm 1.7$ & $33.9 \pm 2.6$ & $65.2 \pm 4.1$ & $57.2 \pm 2.6$ & $67.9 \pm 10.6$ \\
\hline \multirow[t]{3}{*}{ R. oligosporus } & $73-75$ & $34.6 \pm 3.5$ & $126 \pm 5.7$ & $176 \pm 9.9$ & $204 \pm 8.5$ & $187 \pm 7.1$ & $56.3 \pm 3.4$ & $187 \pm 2.8$ & $238 \pm 8.5$ & $212 \pm 11.3$ & $209 \pm 4.2$ & $49.5 \pm 5.5$ & $197 \pm 7.1$ & $249 \pm 4.2$ & $225 \pm 11.3$ & $217 \pm 4.3$ \\
\hline & $84-86$ & $46.5 \pm 5.9$ & $134 \pm 5.7$ & $198 \pm 9.9$ & $226 \pm 5.6$ & $223 \pm 4.2$ & $57.7 \pm 5.2$ & $198 \pm 9.9$ & $265 \pm 9.9$ & $243 \pm 21.2$ & $224 \pm 18.3$ & $68.7 \pm 3.3$ & $228 \pm 8.5$ & $282 \pm 17.0$ & $264 \pm 25.5$ & $245 \pm 14.1$ \\
\hline & $95-97$ & $58.4 \pm 4.5$ & $149 \pm 5.7$ & $213 \pm 9.9$ & $238 \pm 11.3$ & $225 \pm 5.7$ & $67.5 \pm 3.8$ & $176 \pm 8.5$ & $287 \pm 9.9$ & $257 \pm 5.7$ & $253 \pm 8.5$ & $76.1 \pm 5.8$ & $249 \pm 7.1$ & $288 \pm 17.0$ & $274 \pm 8.5$ & $259 \pm 12.7$ \\
\hline \multicolumn{17}{|c|}{ Data represent averages \pm standard deviations of duplicate analyses of duplicate samples. } \\
\hline \multicolumn{17}{|l|}{ Table 4} \\
\hline \multirow[t]{4}{*}{ Mould } & $\mathrm{RH}(\%)$ & \multicolumn{15}{|c|}{ Temperature $\left({ }^{\circ} \mathrm{C}\right)$} \\
\hline & & \multicolumn{5}{|l|}{25} & \multicolumn{5}{|l|}{30} & \multicolumn{5}{|l|}{35} \\
\hline & & \multicolumn{5}{|c|}{ Incubation time $(\mathrm{h})$} & \multicolumn{5}{|c|}{ Incubation time $(\mathrm{h})$} & \multicolumn{5}{|c|}{ Incubation time $(\mathrm{h})$} \\
\hline & & 12 & 24 & 36 & 48 & 60 & 12 & 24 & 36 & 48 & 60 & 12 & 24 & 36 & 48 & 60 \\
\hline \multirow[t]{3}{*}{ A. elegans } & $73-75$ & $25.3 \pm 1.8$ & $57.1 \pm 4.2$ & $91.2 \pm 5.5$ & $105 \pm 7.7$ & $110 \pm 5.4$ & $24.5 \pm 2.7$ & $68.1 \pm 3.7$ & $95.7 \pm 8.9$ & $111 \pm 4.8$ & $121 \pm 10.4$ & $8.35 \pm 1.1$ & $23.8 \pm 1.6$ & $36.4 \pm 3.1$ & $31.5 \pm 1.6$ & $32.6 \pm 3.3$ \\
\hline & $84-86$ & $34.2 \pm 1.5$ & $76.4 \pm 7.9$ & $128 \pm 9.4$ & $147 \pm 9.6$ & $136 \pm 9.3$ & $35.4 \pm 1.9$ & $77.6 \pm 7.1$ & $128 \pm 5.6$ & $167 \pm 13.2$ & $155 \pm 9.8$ & $8.26 \pm 2.0$ & $24.6 \pm 3.3$ & $28.4 \pm 2.0$ & $27.8 \pm 2.4$ & $24.5 \pm 2.8$ \\
\hline & $95-97$ & $49.2 \pm 3.4$ & $95.8 \pm 7.7$ & $158 \pm 11.1$ & $176 \pm 12.0$ & $167 \pm 7.1$ & $36.5 \pm 3.6$ & $72.3 \pm 4.0$ & $139 \pm 10.2$ & $168 \pm 11.8$ & $159 \pm 4.7$ & $8.41 \pm 0.8$ & $31.2 \pm 2.1$ & $33.4 \pm 1.9$ & $36.1 \pm 3.7$ & $35.6 \pm 4.2$ \\
\hline \multirow[t]{3}{*}{ R. oligosporus } & $73-75$ & $16.2 \pm 1.2$ & $48.7 \pm 6.4$ & $98.3 \pm 4.3$ & $106 \pm 9.4$ & $103 \pm 5.0$ & $19.3 \pm 1.7$ & $55.8 \pm 2.5$ & $110 \pm 6.1$ & $118 \pm 6.9$ & $116 \pm 9.3$ & $34.2 \pm 4.5$ & $67.5 \pm 3.9$ & $127 \pm 9.1$ & $145 \pm 8.4$ & $138 \pm 11.2$ \\
\hline & $84-86$ & $27.1 \pm 1.8$ & $61.4 \pm 3.8$ & $119 \pm 2.8$ & $128 \pm 6.7$ & $118 \pm 10.4$ & $43.6 \pm 2.8$ & $71.5 \pm 3.8$ & $146 \pm 11.3$ & $154 \pm 10.9$ & $136 \pm 13.2$ & $46.3 \pm 5.3$ & $97.5 \pm 7.9$ & $167 \pm 12.0$ & $178 \pm 14.7$ & $164 \pm 8.6$ \\
\hline & $95-97$ & $27.9 \pm 2.6$ & $79.4 \pm 6.9$ & $164 \pm 10.3$ & $169 \pm 9.4$ & $171 \pm 12.3$ & $58.4 \pm 4.4$ & $83.2 \pm 7.7$ & $179 \pm 8.9$ & $170 \pm 11.0$ & $176 \pm 12.1$ & $58.4 \pm 3.2$ & $106 \pm 6.5$ & $187 \pm 11.8$ & $176 \pm 12.6$ & $177 \pm 11.5$ \\
\hline
\end{tabular}

Data represent averages \pm standard deviations of duplicate analyses of duplicate samples. 
of glutaminase are a favourable prerequisite for production of pehtze with highly appreciated palatability.

Soybean contains low-molecular-weight saccharides such as stachyose and raffinose, which may be involved in flatulence resulting from ingestion of soybean products. Hydrolysis of stachyose and raffinose by $\alpha$-galactosidase has been suggested as a way to resolve the flatulence problem (Hayakawa, Mizutani, Wada, Masai, Yoshihara, \& Mitsuoka, 1990; Sugimoto \& van Buren, 1970). Therefore, it is of interest to investigate $\alpha$-galactosidase production by $A$. elegans and $R$. oligosporus.

Within the conditions investigated (Table 5), A. elegans produced the highest $\alpha$-galactosidase activity (227 U/g pehtze d.m.) at $30{ }^{\circ} \mathrm{C}$ and $\mathrm{RH} 95-97 \%$ after $60 \mathrm{~h}$ of incubation. $R$. oligosporus yielded the highest $\alpha$-galactosidase activity (226 U/g pehtze d.m.) at $30{ }^{\circ} \mathrm{C}$ and $\mathrm{RH}$ 95-97\% after $36 \mathrm{~h}$ of incubation. The optimum temperature for production of $\alpha$-galactosidase by both moulds was $30{ }^{\circ} \mathrm{C}$, which did not exactly follow the trends of optimum growth temperatures. We observed that $A$. elegans grows well at $25-30{ }^{\circ} \mathrm{C}$ and RH $84-97 \%$, and produces considerable enzyme activities after $48 \mathrm{~h}$, whereas it poorly tolerates higher temperatures $\left(35^{\circ} \mathrm{C}\right)$. On the other hand, $R$. oligosporus could grow very well at $35-40{ }^{\circ} \mathrm{C}$, and yield a very similar pattern of enzyme activity when compared with $A$. elegans. We conclude that, from the point of view of growth and extracellular enzyme production, $R$. oligosporus is able to produce similar levels of biomass and enzyme activities as $A$. elegans at temperatures that are about $10{ }^{\circ} \mathrm{C}$ higher than those tolerated by the latter. Therefore, R. oligosporus could be an alternative for A. elegans as the starter of sufu production during hot seasons. It remains to be established whether or not sufu produced with $R$. oligosporus has a flavour and taste similar to sufu from $A$. elegans.

The flavour and texture of sufu that develop during the aging are determined by the enzymes produced by the mould in pehtze. There is so far no indication of metabolites also contributing to the flavour. The data obtained in this study demonstrate that growth and enzyme production by $A$. elegans and $R$. oligosporus on tofu were influenced by incubation temperature, humidity, and time. From these results it is obvious that sufu manufacturers should pay attention to the control of these conditions. The fluctuation of incubation conditions could result in sub-optimum flavour and texture, or even in putrefaction. Control of incubation conditions will also contribute to reduce the variability in quality from batch to batch.

In conclusion $R$. oligosporus has been shown to have similar growth and enzyme production abilities as $A$. elegans. Consequently it will now be of interest to evaluate the feasibility and acceptability of the use of $R h i$ zopus strains in sufu production.

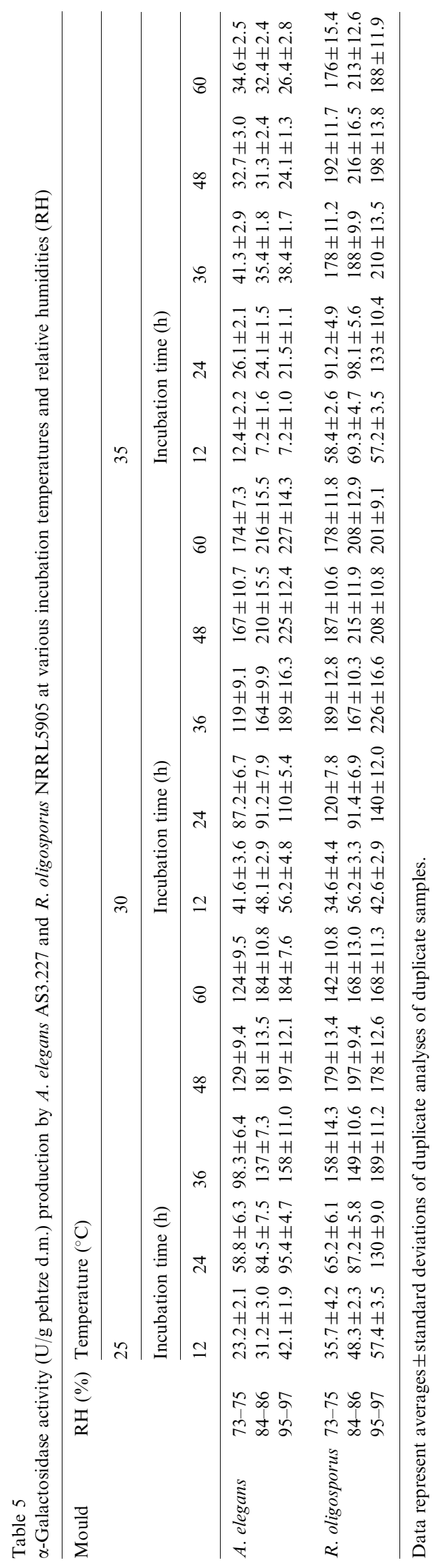




\section{Acknowledgements}

This research was supported by the Graduate School VLAG, Wageningen University, The Netherlands and Beijing WangZhiHe Sufu Manufacture, China.

\section{References}

Chou, C.-C., Ho, F.-M., \& Tsai, C.-S. (1988). Effects of temperature and relative humidity on the growth of and enzyme production by Actinomucor taiwanensis during sufu pehtze preparation. Applied and Environment Microbiology, 54(3), 688-692.

Halpern, B. P. (2000). The use and utility of glutamates as flavoring agents in food-glutamate and the flavor of food. Journal of Nutrition, 130, 910S-914S.

Han, B.-Z., \& Nout, M. J. R. (2000). Effects of temperature, water activity and gas atmosphere on mycelial growth of tempe fungi Rhizopus microsporus var. microsporus and $R$. microsporus var. oligosporus. World Journal of Microbiology \& Biotechnology, 16, 853-858.

Han, B.-Z., Rombouts, F. M., \& Nout, M. J. R. (2001). A Chinese fermented soybean food. International Journal of Food Microbiology, 65(1-2), 1-10.

Hayakawa, K., Mizutani, J., Wada, K., Masai, T., Yoshihara, I., \& Mitsuoka, T. (1990). Effects of soybean oligosaccharides on human faecal flora. Microbial Ecology in Health \& Disease, 3, 293-303.

Kruger, J. E. (1973). Change in the levels of proteolytic enzymes from hard red spring wheat during growth and maturation. Cereal Chemistry, 5, 122-131.

Liu, Y.-H., \& Chou, C.-C. (1994). Contents of various types of proteins and water soluble peptides in sufu during aging and the amino acid composition of tasty oligopeptides. Journal of the Chinese Agricultural Chemical Society, 32(3), 276-283 (in Chinese, with English abstract).
Lu, J.-M., Yu, R.-C., \& Chou, C.-C. (1996). Purification and some properties of glutaminase from Actinomucor taiwanensis, starter of sufu. Journal of the Science of Food and Agriculture, 70, 509-514.

Mitchell, D. A., Doelle, H. W., \& Greenfield, P. F. (1989). Suppression of penetrative hyphae of Rhizopus oligosporus by membrane filters in a model solid-state fermentation system. Biotechnology Techniques, 3(1), 45-50.

Moriguchi, M., Sakai, K., Tateyama, R., Furuta, Y., \& Wakayama, M. (1994). Isolation and characterization of salt-tolerant glutaminases from marine Micrococcus luteus K-3. Journal of Fermentation \& Bioengineering, 77(6), 621-625.

Nagel, F. J. I., Oostra, J., Tramper, J., \& Rinzema, A. (1999). Improved model system for solid-substrate fermentation. Process Biochemistry, 35, 69-75.

Steinkraus, K. H. (1996). Chinese sufu. In K. H. Steinkraus (Ed.), Handbook of indigenous fermented foods (pp. 633-641). New York, Basel, Hong Kong: Marcel Dekker.

Su, Y. C. (1986). Sufu. In N. R. Reddy, M. D. Pierson, \& D. K. Salunkhe (Eds.), Legume-based fermented foods (pp. 69-83). Boca Raton, Florida, USA: CRC Press.

Sugimoto, H., \& van Buren, J. P. (1970). Removal of oligosaccharides from soy milk by an enzyme from Aspergillus saitoi. Journal of Food Science, 35, 655-660.

Van den Broek, L. A. M., Ton, J., Verdoes, J. C., van Laere, K. M. J., Voragen, A. G. J., \& Beldman, G. (1999). Synthesis of $\alpha$-galactooligosaccharides by a cloned $\alpha$-galactosidase from Bifidobacterium adolescentis. Biotechnology Letters, 21, 441-445.

Wang, H. L., \& Hesseltine, C. W. (1970). Sufu and Lao-Chao. Journal of Agricultural and Food Chemistry, 18(4), 572-575.

Wang, H. L., Vespa, J. B., \& Hesseltine, C. W. (1974). Acid protease production by fungi used in soybean food fermentation. Applied Microbiolology, 27, 906-911.

Wang, R.-Z., \& Du, X.-X. (1998). The production of Sufu in China (in Chinese). Beijing, China: China Light Industry Press. 